\title{
Characterization of six flagellin genes in the H3, H53 and H54 standard strains of Escherichia coli
}

\author{
Akira Tominaga \\ Department of Biology, Faculty of Science, Okayama University, Okayama 700-8530, Japan
}

(Received 17 December 2003, accepted 19 January 2004)

\begin{abstract}
Six flagellin genes in three H standard Escherichia coli strains for H3, H53 and H54 were characterized. Each strain has two flagellin genes, one of which is expressed as its standard $\mathrm{H}$ antigen. A pair of flagellin genes $f l k A 3$ (encoding for $\mathrm{H} 3$ antigen) and fliC16 (H16) was cloned from Bi7327-41, flkA53 (H53) and fliC53 from E480-68, and flmA54 (H54) and fliC-54 from E223-69. Two fliC genes, fliC-53 and fliC-54, are nonfunctional owing to the insertions of IS1 and IS1222, respectively. The flkA and $f l m A$ regions are located in the 3 ' end of the $r n p B$ gene and near the $n l p A$ gene, respectively. Each of them is followed by a gene homologous to fljA, which is known to repress the expression of fliC(i) in Salmonella enterica serovar Typhimurium. These results suggest that they are derived from the same origin of the $f l j B A$ operon. However, these regions contain neither the hin gene nor the invertible $\mathrm{H}$ segment. The four flagellin genes, fliC16, flkA3, flkA53 and flmA54, share high homology in nucleotide and amino-acid sequences with one another and with the $S$. enterica serovar Typhimurium flagellin genes. The promoter sequence of fliC16 is homologous to that of $f l i C(\mathrm{i})$, whereas the promoter sequences of $f l k A$ and $f l m A$ are homologous to that of $f l j B$. The terminator sequences of the fliC16, fliC-53 and fliC-54 genes are conserved among themselves and identical with that of the $E$. coli fliC48 gene. Three FljA repressors, FljA3, FljA53 and FljA54, are homologous highly with one another and moderately with FljA of Salmonella. These results indicate that six flagellin genes analyzed are markedly similar to the Salmonella flagellin genes, suggesting their lateral transfer from Salmonella.
\end{abstract}

Key words: Escherichia coli, flagellin gene, $\mathrm{H}$ antigen, lateral transfer

\section{INTRODUCTION}

Although there is little evolutionary divergence between Escherichia coli and Salmonella enterica serovar Typhimurium (Ochman and Wilson, 1987), one remarkable difference between them is in the flagellar gene system: in $E$. coli K-12 one flagellin gene fliC48 (encoding for $\mathrm{H} 48$ antigen) located at $43.1 \mathrm{~min}$ is constitutively expressed, while in S. enterica serovar Typhimurium two flagellin genes $f l i C(\mathrm{i})$ and $f l j B$, located at $42.5 \mathrm{~min}$ and 60 min, respectively, are expressed alternatively by the phase variation mechanism (Zieg et al., 1977). This mechanism is controlled by orientation of the invertible $\mathrm{H}$ segment (Zieg and Simon, 1980) upstream of the $f l j B A$ operon: in the $\mathrm{H}(+)$ orientation the operon is expressed and the fljA product (FljA) represses expression of the fliC(i) gene (Silverman et al., 1979; Hanafusa et al., 1993)

Edited by Hideo Shinagawa

* Corresponding author. E-mail: atomi@cc.okayama-u.ac.jp resulting in only FljB flagellin being expressed, whereas in the $\mathrm{H}(-)$ orientation the operon is inactive, resulting in FliC(i) flagellin being expressed. The $\mathrm{H}$ inversion is mediated by a DNA invertase encoded by the hin gene within the H segment (Zieg and Simon, 1980).

Recent studies for the flagellin genes in natural isolates of $E$. coli (Ratiner, 1982, 1987, 1998) demonstrated that some standard $E$. coli strains for $\mathrm{H}$ antigens have another flagellin gene beside $f l i C$. For example, two new flagellin genes, named $f l k A$ and $f l m A$, were mapped near $\arg G$ (69 $\mathrm{min})$ and $m t l A(81 \mathrm{~min})$, respectively. In addition to flagellin, the $f l k A$ and $f l m A$ loci show a repressor activity similar to that of Salmonella FljA, and this repressor represses the expression of some $f l i C$ genes of standard $E$. coli strains but not that of fliC48 (Ratiner, 1998). This work was initiated to gain an insight into diversity of flagellar antigens in natural isolates of $E$. coli. This paper describes molecular characterization of the $f l k A$ and flmA loci of $E$. coli. Structures of the silent fliC genes in the $f l k A$ - or $f l m A$-expressing strains are also 
described. On the basis of the obtained results, I discuss the evolutionary aspect of the divergence of these flagellin genes.

\section{MATERIALS AND METHODS}

Bacterial strains, plasmids and media Bacterial strains used are listed in Table 1. Cloning vectors used were plasmids pBR322 (Bolivar et al., 1977), pACYC184 (Chang and Cohen, 1978) and pSTV28 (Takara). TLY broth, nutrient agar and nutrient semisolid agar (NSS) were as described (Enomoto et al., 1983). Chloramphenicol (Sigma), tetracycline (Sigma) and ampicillin (Sigma) were used at final concentrations of 12.5, 25 and $50 \mu \mathrm{g} /$ $\mathrm{ml}$, respectively. Anti-i serum (Enomoto et al., 1985) was used at a final concentration of $0.05 \%$.

Table 1. Bacterial strains used

\begin{tabular}{|c|c|c|}
\hline Strain & Relevant genotype $^{a}$ & Reference \\
\hline \multicolumn{3}{|c|}{ Escherichia coli } \\
\hline EJ2060 & fliD1101 recA56 & Tominaga et al. 1994 \\
\hline EJ2061 & fliA4181 recA56 & Tominaga et al. 1994 \\
\hline EJ2282 & $\Delta f l i C 48$ recA56 & Tominaga et al. 1991 \\
\hline PM336 & fliC16 $^{\text {on }}(\mathrm{H} 16)$ & Ratiner 1998 \\
\hline Bi7327-41 & $f l k A 3^{\text {on }}, f l i C^{\text {off }}(\mathrm{H} 3)$ & Ratiner 1982 \\
\hline E480-68 & $f l k A 53^{\text {on }}(\mathrm{H} 53)$ & Ratiner 1987 \\
\hline $\mathrm{E} 223-69$ & $f l m A 54^{\text {on }}(\mathrm{H} 54)$ & Ratiner 1998 \\
\hline
\end{tabular}

Salmonella enterica

KK1004 $\quad \Delta f l j B A f l i C(\mathrm{i})^{\text {on }} \quad$ Kutsukake et al. 1988

a. The $\mathrm{H}$ antigen number is postfixed to each flagellin gene. Superscripts: on, expressed; off, cryptic state. The flagellar antigens expressed are indicated in the parentheses.

DNA manipulation and sequencing Genomic DNA was prepared by the method described (Tominaga et al., 1991). Isolation of plasmid DNA, construction of recombinant plasmids, restriction analysis of cloned fragments and transformation were performed using standard methods (Sambrook et al., 1989). Restriction endonucleases and T4 DNA ligase were purchased from Takara and used as recommended. The nonfunctional $f l i C$ regions were PCR-amplified with the primers fliA2 (5'- AACCGCCGAAAACTGTACCGAGA-3') and fliD-S3 (5'- TCCGGATCCGATTGCAAACAGTAG-3') and cloned into pSTV28. Nucleotide sequence was determined by primer walking using a dye terminator cycle-sequencing ready-reaction kit (Applied Biosystems). Nucleotide and amino-acid sequences were analyzed using GENETYX information processing software (Software Development Co.).

Nucleotide sequence data reported are available in the DDBJ/EMBL/GenBank databases under the accession numbers AB128916 to AB128921.

\section{RESULTS AND DISCUSSION}

Cloning of the flagellin genes from the H3 standard strain The standard strain for H3 (Bi7327-41) has two flagellin genes, fliC16 and flkA3, which are in a cryptic and expressed state, respectively. The expression of the fliC16 gene is repressed by an FljA-like activity in this strain (Ratiner, 1982).

For cloning of the fliC16 gene, strain PM336 expressing the fliC16 gene transduced from Bi7327-41 was used as a DNA donor. DNA of PM336 digested with BamHI was inserted into pBR322 and introduced into a non-motile strain EJ2282 $(\Delta f l i C)$. One motile clone was isolated, and a recombinant plasmid within the clone was named pECH16-1. This plasmid was found to contain a $12.6-\mathrm{kb}$ BamHI fragment and confer motility on the strains EJ2282 ( $\Delta f l i C)$, EJ2060 (fliD) and EJ2061 (fliA) (Fig. 1A). As the $f l i C$ gene is flanked by the fliA and $f l i D$ genes in $E$. coli K-12, this result suggests that this flagellin gene locates in the authentic $f l i C$ locus. According to subcloning experiments, the fliC16 gene was finally localized in a $4.5-\mathrm{kb}$ ClaI fragment carried by pECH16-2.

For cloning of the flkA3 gene, DNA of Bi7327-41 was digested with EcoRI, inserted into pACYC184 and introduced into strain EJ2282. One of the motile clones was isolated, and a recombinant plasmid within the clone was named pECH3-1. This plasmid was found to contain a 19.3-kb EcoRI fragment and confer motility on EJ2282 but not on either EJ2060 or EJ2061 (Fig. 1B). According to subcloning experiments, the $f l k A 3$ gene was finally localized onto a $5.5-\mathrm{kb}$ ClaI fragment carried by pECH3-3.

Cloning of the flagellin genes from the standard strains for H53 and H54 The standard strains for H53 (E480-68) and H54 (E223-69) have single functional flagellin genes, flkA53 and flmA54, respectively, and have no functional fliC gene (Ratiner, 1998). For cloning of the flkA53 and flmA54 genes, DNA of E480-68 or E22369 was digested with BamHI, EcoRI or SalI, inserted into pACYC184 and introduced into strain EJ2282. Several motile clones were isolated. One recombinant plasmid pECH53-1 derived from E480-68 contains a 30.6-kb SalI fragment. Two recombinant plasmids pECH54-1 and pECH54-2 derived from E223-69 contain a 25.7-kb $B a m \mathrm{HI}$ fragment and a 13.6-kb EcoRI fragment, respectively (Fig. 1C, 1D). According to subcloning experiments, the $f l k A 53$ and $f l m A 54$ genes were finally localized onto $3.6-\mathrm{kb}$ HindIII and 4.6-kb BamHI-SalI fragments carried by pECH53-3 and pECH54-3, respectively.

To clone the nonfunctional $f l i C$ genes from these strains, the $f l i C$ genes were PCR-amplified with the primers, fliA2 and fliD-S3, and inserted into pSTV28. Recombinant plasmids pECC-53 and pECC-54 contain 2.7-kb E480-68 and 2.4-kb E223-69 fragments, respectively. 
A pECH16-1

pECH16-2

B

pECH3-1

pECH3-2

pECH3-3

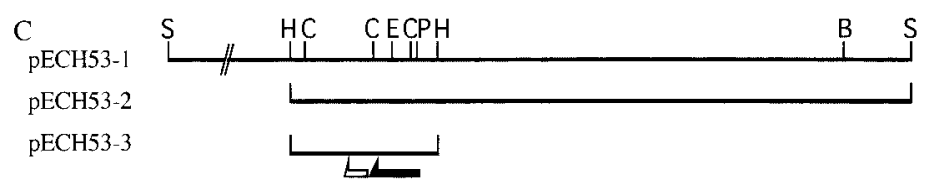

DECH54-1

pECH54-2

pECH54-3
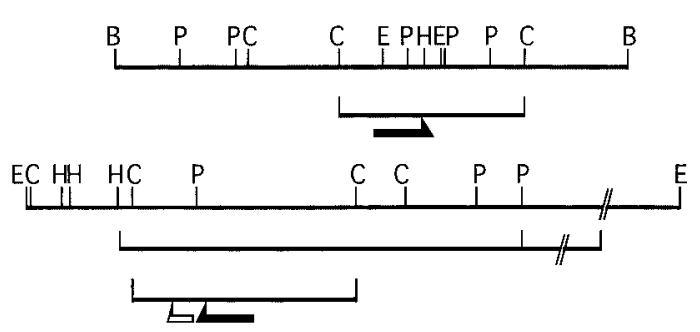

$-\quad+\quad+$

NT + NT +

NT + NT +

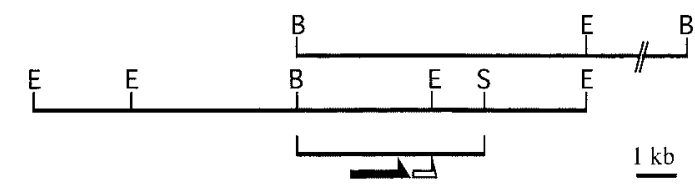

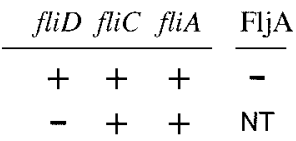

$-+-+$

NT + NT +

$\mathrm{NT}+\mathrm{NT}+$

Fig. 1. Restriction maps of the cloned E. coli DNA fragments containing flagellin genes. Abilities to complement fliD, fliC and fliA mutants and FljA activity to repress the fliC(i) gene of Salmonella are also indicated. The size and transcriptional direction of the flagellin gene and the fljA gene are shown by solid and open arrows, respectively. Cloned fragments were derived from PM336 (A), Bi7327-41 (B), E480-68 (C) and E223-69 (D). Restriction cleavage sites: B, BamHI; C, ClaI; E, EcoRI; H, HindIII; P, PstI; S, SalI. NT, not tested.

FljA repressor activity To detect the FljA-like repressor activity in the cloned flkA and $f l m A$ loci, each recombinant plasmid (pECH3-1, pECH53-1 or pECH54-1) was introduced into a Salmonella $\triangle$ fljBA mutant (KK1004 $\left.f l i C(\mathrm{i})^{\mathrm{on}}\right)$, and the motility was examined on an NSS plate with or without anti-i serum. All recombinant plasmids conferred motility even in the presence of anti-i serum, though the motility of KK1004 was completely inhibited by anti-i serum. This indicates that the $f l i C(i)$ gene was repressed by the FljA-like activity on the plasmids. This
FljA-like activity was also detected on smaller plasmids (pECH3-3, pECH53-3 and pECH54-3). Genes for this repressor activity were named fljA3, fljA53 and fljA54, respectively.

Sequence analysis of the flkA and flmA loci The flkA and $f l m A$ genes and their flanking regions were sequenced. Gene organization deduced from the determined nucleotide sequences are summarized in Fig. 2. Comparison to the genome organization of $E$. coli K-12

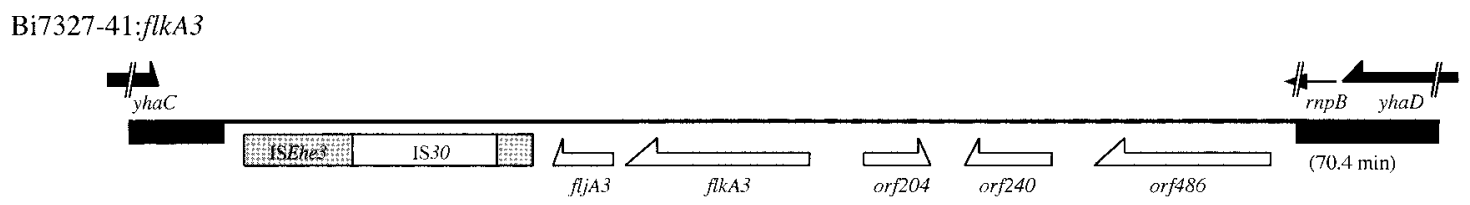

E480-68: flkA53
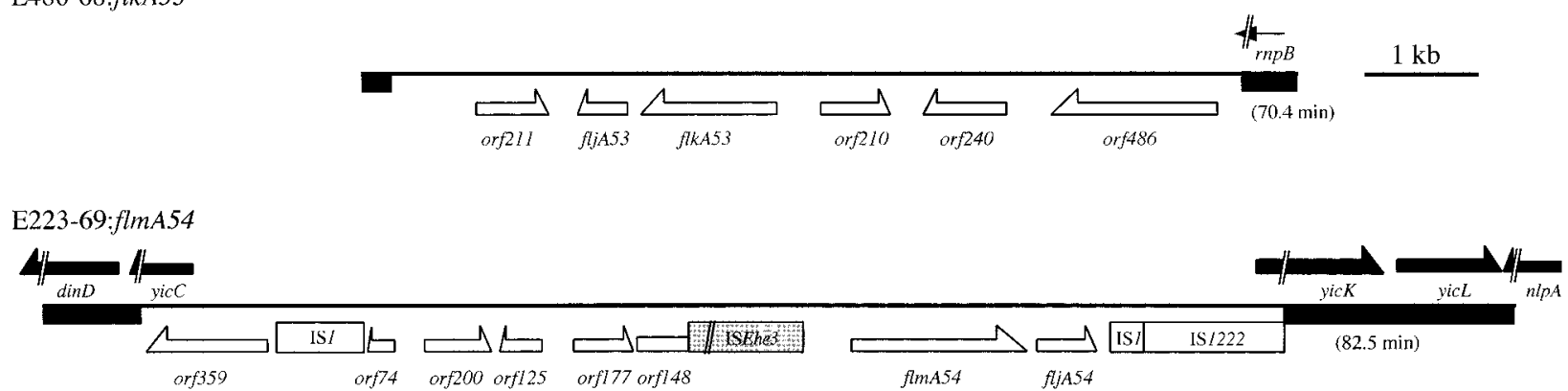

Fig. 2. Gene organization of the flagellin genes, $f l k A$ and $f l m A$ and their flanking regions. Thin lines indicate DNA regions unique to the strains analyzed, whereas thick lines indicate the DNA regions conserved in E. coli K- 12 . Arrows above the lines show $E$. coli K-12 genes. Newly identified orfs are indicated by open arrows and named after number of amino acids they encode. IS elements are indicated by rectangles. They are homologous more than $92 \%$ to the known elements in DDBJ/EMBL/GenBank databases. 
indicates that the flkA loci in strains Bi7327-41 and E480-68 are located at the identical position in the 3' region of the $\operatorname{rnp} B$ gene, which exists at $70.4 \mathrm{~min}$ in the $E$. coli K-12 genome. This suggests that these flkA regions might have been derived from a common ancestor. The flmA region in E223-69 is flanked by truncated $y i c C$ and $y i c K$ genes, which locate $19.4 \mathrm{~kb}$ apart from each other near $82.5 \mathrm{~min}$ in $E$. coli $\mathrm{K}-12$. This suggests that the 19.4-kb DNA region of K-12 might have been replaced by the flmA locus in E223-69. The yicC and $y i c K$ genes are transcribed in the same direction in E. coli K-12 but in the opposite directions in E223-69, suggesting that this DNA region had been subjected to genomic rearrangement after or at the time of its integration.

Flagellin genes were identified on the basis of the homology with known flagellin genes (Fig. 2). The predicted gene sizes of $f l k A 3, f l k A 53$ and flmA54 are $1,587 \mathrm{bp}$ (529 amino-acid residues [a.a.], 55,567 Da), 1269 bp (423 a.a., 44,887 Da) and 1548 bp (516 a.a., 54,451 Da), respectively. All of these flagellin genes are followed by genes homologous to Salmonella fljA, which are named fljA3, fljA53 and fljA54, respectively. They consist of 522 bp (174 a.a., 19,734 Da), 522 bp (174 a.a., 19,750 Da) and $525 \mathrm{bp}$ (175 a.a., 19,746 Da), respectively. However, these flagellin genes are not accompanied with either the hin gene or the invertible $\mathrm{H}$ segment, suggesting these are expressed constantly.

The replaced DNA regions have no sequence homology to any sequences in DDBJ/EMBL/GenBank databases except for IS elements and flagellum-related sequences.
Though the two flkA regions in Bi7327-41 and E480-68 are homologous to each other, the regions downstream of the $f l j A$ gene are divergent. In Bi7327-41, that region contains an ISEhe3 element (Guo et al., 2002), into which an IS30 element (Dalrymple et al., 1984) is inserted further. A predicted ORF211 of E480-68 is partially homologous to a hypothetical protein YxkC (213 a.a.) of Bacillus subtilis (Kunst et al., 1997).

More than 4-kb sequences upstream of the two flkA genes are 98\% homologous to each other, and the aminoacid sequences of the predicted ORFs, ORF204 of Bi7327-41 and ORF210 of E480-68, ORF240 of both strains and ORF486 of both strains exhibit more than 99\% homology. Both ORF204 and ORF210 are 43.8\% homologous to the PinR protein (196 a.a.) of lambdoid prophage Rac (Blattner et al., 1997), which belongs to the DNA invertase/resolvase family as well as the Salmonella Hin protein (Johnson, 2002). The organization of orf204, flkA3 and fljA3 in Bi7327-41 or orf210, flkA53 and fljA53 in E480-68 is reminiscent of that of the hin gene and the fljBA operon in $S$. enterica serovar Typhimurium, suggesting that these three loci might have been derived from a common ancestor. ORF240 and ORF486 are partially homologous to a hypothetical protein VV2259 (212 a.a.) of Vibrio vulnificus (Chen et al., 2003) and a probable integrase/recombinase family protein XCC1597 (488 a.a.) of Xanthomonas campestris (da Silva et al., 2002), respectively.

The flmA locus in E223-69 contains insertions of one ISEhe3 with an internal deletion and two IS1s (Umeda and Ohtsubo, 1991), one of which is disrupted by a sec-

Table 2. Homology of the 5'and 3' constant sequences among flagellin genes and molecules

\begin{tabular}{|c|c|c|c|c|c|c|c|c|}
\hline Gene & & flkA3 & $f l k A 53$ & flmA54 & fliC16 & fliC48 & $f l i C(\mathrm{i})$ & $f l j B$ \\
\hline \multirow[t]{2}{*}{$f l k A 3$} & $\mathrm{~N}$ & & 0.78 (518) & $0.78(520)$ & $0.79(520)$ & $0.74(520)$ & $0.77(512)$ & $0.77(512)$ \\
\hline & $\mathrm{A}$ & & 0.84 (173) & 0.86 & $0.92(173)$ & 0.84 (173) & $0.83(173)$ & $0.83(173)$ \\
\hline \multirow[t]{2}{*}{$f l k A 53$} & $\mathrm{~N}$ & 0.80 & & $0.79(515)$ & $0.75(518)$ & $0.74(511)$ & $0.78(511)$ & $0.77(511)$ \\
\hline & $\mathrm{A}$ & $0.86(92)$ & & 0.86 & 0.86 & $0.79(173)$ & 0.86 & 0.86 \\
\hline \multirow[t]{2}{*}{ flmA54 } & $\mathrm{N}$ & $0.79(276)$ & $0.78(260)$ & & $0.80(520)$ & $0.73(520)$ & $0.79(520)$ & $0.78(520)$ \\
\hline & $\mathrm{A}$ & $0.87(92)$ & $0.83(93)$ & & 0.89 (173) & 0.84 (171) & $0.91(173)$ & 0.91 (173) \\
\hline \multirow[t]{2}{*}{ fliC16 } & $\mathrm{N}$ & $0.83(280)$ & $0.80(274)$ & 0.77 (277) & & $0.75(520)$ & $0.78(514)$ & $0.76(518)$ \\
\hline & $\mathrm{A}$ & $0.91(93)$ & $0.84(92)$ & $0.89(92)$ & & 0.84 (173) & 0.84 (173) & $0.84(173)$ \\
\hline \multirow[t]{2}{*}{ fliC48 } & $\mathrm{N}$ & 0.68 (274) & $0.64(274)$ & $0.65(264)$ & $0.70(272)$ & & 0.79 & $0.78(512)$ \\
\hline & A & $0.73(91)$ & $0.67(91)$ & $0.70(91)$ & $0.75(91)$ & & 0.79 (173) & 0.79 (173) \\
\hline \multirow[t]{2}{*}{$f l i C(\mathrm{i})$} & $\mathrm{N}$ & $0.79(276)$ & $0.76(251)$ & 0.78 (279) & $0.78(277)$ & $0.71(271)$ & & $0.98(520)$ \\
\hline & $\mathrm{A}$ & $0.87(92)$ & $0.81(93)$ & 0.87 (93) & $0.85(92)$ & $0.69(91)$ & & 0.99 (173) \\
\hline \multirow[t]{2}{*}{$f l j B$} & $\mathrm{~N}$ & $0.79(276)$ & $0.74(251)$ & 0.75 (279) & $0.78(277)$ & 0.70 & $0.89(280)$ & \\
\hline & A & $0.87(92)$ & $0.82(92)$ & $0.87(92)$ & $0.85(92)$ & $0.71(91)$ & $0.97(92)$ & \\
\hline
\end{tabular}

A pair of nucleotide sequences, $520 \mathrm{bp}$ for the 5' sequence and $280 \mathrm{bp}$ for the 3 ' sequence, was compared by maximum homology alignment. Predicted amino-acid sequences were also compared. The numbers in parentheses show the numbers of nucleotides or amino acids used for comparison. Homology in the 5' and 3' sequences is shown above and under the slanted line, respectively. Flagellin genes are named after their $\mathrm{H}$ antigen types. N, nucleotide sequence; $\mathrm{A}$, amino-acid sequence. 
ondary insertion of IS1222 (Steibl and Lewecke, 1995). The insertion site of the intact IS 1 is flanked by 9-bp direct repeats. The nine bp direct repeat might be target duplication, suggesting that this insertion was a recent event of evolution. Among six ORFs predicted, only three (ORF74, ORF125 and ORF148) show aminoacid sequence homology to those in protein databases. ORF74 is $37 \%$ homologous to a hypothetical protein Rsc0962 of Ralstonia solanacearum (Salanoubat et al., 2002), which has a DNA-binding domain of the transcrip-

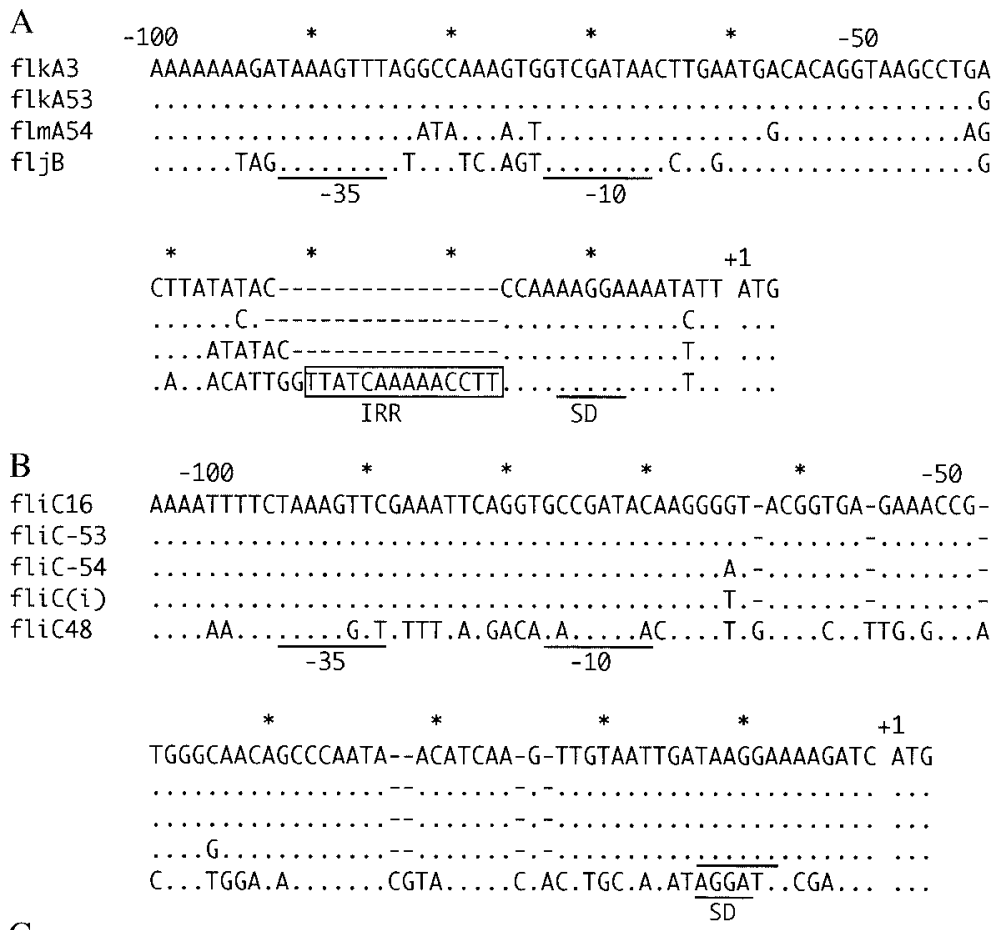

C

flkA53

$f \operatorname{lmA54}$

$f l j B$

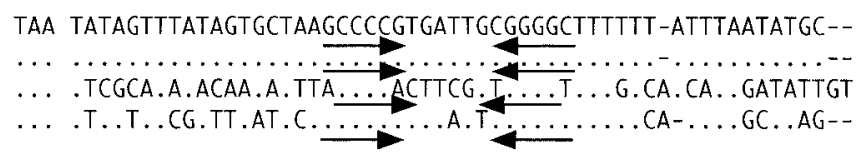

TAAAAGTCGGTTATTAG--GTA-CAACTG--TT ATG

$f l j A$

САAАGICGG

.T.TC. . AATG.T... TT . . GGT. T. .CTCA ...

D

. . . ATATA- - T. T- - . . .

flic16 TAA TTTACACTTATCGCTCAAACCCCGCCACCGGCGGGGTTTTTT-CTGCATGGAATTT

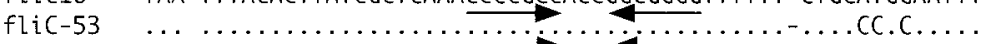

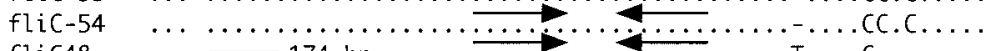

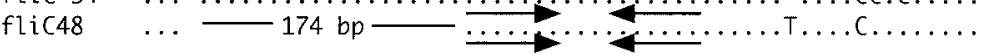

ACCGGTAACCCCCAAATAACCCCTCATTTCACCCACTAATCGTCCGATTAAAAACCCTGC

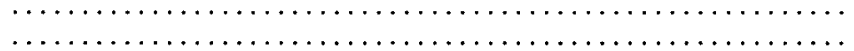

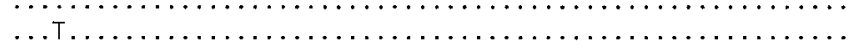

AGAAACGGATAATCATGCCGATAACTCATATAACGCAGGGCTGTTTATC GTG FliA

Fig. 3. Comparison of the upstream (A, B) and downstream (C, D) sequences of the flagellin genes. A, B: The sequences are numbered from the first nucleotide $(+1)$ of the start codon. $\sigma^{28}$-dependent promoter and SD sequences are underlined. The boxed sequence in $f l j B$ is the right one of the inverted repeats (IRR) of the $\mathrm{H}$ segment (Zieg and Simon, 1980). C, D: The sequences including the stop codon (TAA) for the flagellin gene and the start codon (ATG or GTG) for the next gene (fljA or $f l i A)$ are shown. Putative terminator sequences are shown by converging arrows. 
tional regulator AlpA of the cryptic prophage CP457. ORF125 is 54\% homologous to the fimbrial protein MrfJ of Photorhabdus luminescens (Duchaud, et al., 2003), which contains a helix-turn-helix motif specific for DNA-binding proteins. ORF148 is partially homologous to a putative lipoprotein Reut4794 of Ralstonia metallidurans.

Sequence analysis of the $\boldsymbol{f l i C}$ genes Three $f l i C$ genes cloned were also sequenced. The functional fliC16 gene from Bi7327-41 consists of 1572 bp (524 a.a., 55,039 $\mathrm{Da})$. Two nonfunctional $\mathrm{fliC}$ genes, $\mathrm{fliC}-53$ from $\mathrm{E} 480-68$ and fliC-54 from E223-69, are interrupted by insertions of IS1 and IS1222, respectively. A target duplication of 8 bp is present at the insertion site of IS1 into fliC-53. The presumed intact fliC-53 gene consists of $1476 \mathrm{bp}$ (492 a.a., $51,660 \mathrm{Da})$ and is highly homologous $(98 \%)$ to the $\mathrm{fliC}$ gene for $\mathrm{H} 40$ antigen. In the fliC-54 gene, no target duplication can be detected at either side of IS1222. If this IS1222 sequence is removed, the resulting $\mathrm{fliC}$ gene should encode a protein too small to form flagellar filaments (Kuwajima 1988). Therefore, it is assumed that two IS1222 elements might have been integrated independently into different sites of the ancient fliC gene and a subsequent homologous recombination between them resulted in deletion of the central region.

Comparison of protein and gene sequences of flagellin and FljA The molecular masses of flagellin from strains PM336, Bi7327-41, E480-68 and E223-69 were estimated by SDS-PAGE to be $54 \mathrm{kDa}, 54 \mathrm{kDa}, 43 \mathrm{kDa}$ and $53 \mathrm{kDa}$, respectively, which are in a reasonable agreement with those deduced from nucleotide sequences of fliC16, flkA3, flkA53 and flmA54 genes, respectively (data not shown).

Flagellin genes are generally composed of three structural parts, 5'-constant, central variable and 3'-constant regions. Comparison of the 5'- or 3'-constant sequence of the newly analyzed flagellin genes with those of $E$. coli K12 and S. enterica serovar Typhimurium is shown in Table 2. The flkA, flmA and fliC16 genes show higher similarity with those of Salmonella for both 5'- and 3'-constant sequences, suggesting that these three genes are close relatives of the Salmonella flagellin genes. Similarities were also observed in the amino-acid sequences predicted from the nucleotide sequences. Marked similarities are observed in the promoter regions among the $f l k A, f l m A$ and $f l j B$ genes. However, the inverted repeat sequence responsible for invertible recombination of the $\mathrm{H}$ segment is absent in the $f l k A$ and $f l m A$ genes (Fig. 3A). The 105-bp regions upstream of the fliC16, fliC-53 and $f l i C-54$ are almost identical with that of $f l i C(\mathrm{i})$ of $\mathrm{Sal}$ monella (Fig. 3B), which contains its promoter and operator sequences (Hanafusa et al., 1989, Ide et al., 1999, Inoue et al., 1989). This suggests that both $f l i C-53$ and $f l i C$ - 54 genes are also repressed by FljA. The $f l i C$ genes might have been inactivated by IS insertions during their repressed state in strains E480-68 and E223-69. The intergenic regions between the fliC (fliC16, fliC-53 or fliC-54) and fliA genes are identical except for 3-bp mismatch. Each of these regions contains a $\rho$-independent terminator-like sequence identical to that of fliC48 (Fig. 3D). These regions show no sequence similarity to the region downstream of the Salmonella fliC gene.

Comparison of the FljA repressors is shown in Table 3. FljA3 and FljA53 show 98\% homology with each other and $83 \%$ and $85 \%$ homology with FljA54, respectively. Homology of the FljA repressors of $E$. coli with that of Salmonella is less than $70 \%$, indicating that the $f l j A$ genes in E. coli had diverged from that of Salmonella and have been evolving independently. A $\rho$-independent terminator, that is known to attenuate the fljA expression in Salmonella (Hanafusa et al., 1993), is also present in the intergenic regions of $f l k A$ or $f l m A$ and fljA (Fig. 3C).

Table 3. Homology of FljA repressor

\begin{tabular}{|c|c|c|c|c|c|}
\hline Gene & Protein & FljA3 & FljA53 & FljA54 & FljA \\
\hline fljA3 & & & 0.99 (174) & $0.83(174)$ & $0.68(174)$ \\
\hline fljA53 & & $0.97(522)$ & & $0.84(174)$ & 0.68 (174) \\
\hline fljA54 & & $0.85(521)$ & $0.85(521)$ & & 0.69 (173) \\
\hline$f l j A$ & & $0.71(520)$ & $0.71(520)$ & $0.70(520)$ & \\
\hline
\end{tabular}

Nucleotide sequences and predicted amino-acid sequences were compared by maximum homology alignment. The numbers in parentheses show the numbers of nucleotides or amino acids used for comparison. Homology between the amino-acid sequences and between the nucleotide sequences is shown above and under the slant line, respectively.

Conclusions Flagellin genes from the H3, H53 and H54 standard strains of $E$. coli were sequenced and compared with known flagellin genes. All the flagellin genes show marked similarity to the Salmonella flagellin genes, suggesting their lateral transfer from Salmonella. The $f l k A$ and $f l m A$ genes are flanked by IS elements and genes involved in the recombination of mobile DNAs, suggesting that these genes might have been transferred as parts of transposable units and subjected to many structural changes such as rearrangements mediated by IS elements.

\section{REFERENCES}

Blattner, F.R., Plunkett, G. III, Bloch, C. A., Perna, N. T., Burland, V., Riley, M., Collado-Vides, J., Glasner, J. D., Rode, C. K., Mayhew, G. F., Gregor, J., Davis, N. W., Kirkpatrick, H. A., Goeden, M. A., Rose, D. J., Mau, B. and Shao, Y. (1997) The complete genome sequence of Escherichia coli K12. Science 277, 1453-1474.

Bolivar, F., Rodoriguez, R. L., Greene, P. J., Betlach, M. C., Hey- 
neker, H. L., Boyer, H. W., Cross, J. H. and Falkow, S. (1977) Construction and characterization of new cloning vehicles. II. A multi-purpose cloning system. Gene 2, 95113.

Chang, A. Y. C. and Cohen, S. N. (1978) Construction and characterization of amplifiable multicopy DNA cloning vehicles derived from the P15A cryptic miniplasmid. J. Bacteriol. 134, 1141-1156.

Chen, C. Y., Wu, K. M., Chang, Y. C., Chang, C. H., Tsai, H. C., Liao, T. L., Liu, Y. M., Chen, H. J., Shen, A. B., Li, J. C., Su, T. L., Shao, C. P., Lee, C. T., Hor, L. I. and Tsai, S. F. (2003) Comparative genome analysis of Vibrio vulnificus, a marine pathogen. Genome Res. 13, 2577-2587.

Dalrymple, B., Caspers, P. and Arber, W. (1984) Nucleotide sequence of the prokaryotic mobile genetic element IS30. EMBO J. 3, 2145-2149.

da Silva, A. C. R., Ferro, J. A., Reinach, F. C., Farah, C. S., Furlan, L. R., Quaggio, R. B., Monteiro-Vitorello, C. B., Van Sluys, M. A., Almeida Jr., N. F., Alves, L. M. C., do Amaral, A. M., Bertolini, M. C., Camargo, L. E. A., Camarotte, G., Cannavan, F., Cardozo, J., Chambergo, F., Ciapina, L. P., Cicarelli, R. M. B., Coutinho, L. L., Cursino-Santos, J. R., El-Dorry, H., Faria, J. B., Ferreira, A. J. S., Ferreira, R. C. C., Ferro, M. I. T., Formighieri, E. F., Franco, M. C., Greggio, C. C., Gruber, A., Katsuyama, A. M., Kishi, L. T., Leite Jr., R. P., Lemos, E. G. M., Lemos, M. V. F., Locali, E. C., Machado, M. A., Madeira, A. M. B. N., Martinez-Rossi, N. M., Martins, E. C., Meidanis, J., Menck, C. F. M., Miyaki, C. Y., Moon, D. H., Moreira, L. M., Novo, M. T. M., Okura, V. K., Oliveira, M. C., Oliveira, V. R., Pereira Jr., H. A., Rossi, A., Sena, J. A. D., Silva, C., de Souza, R. F., Spinola, L. A. F., Takita, M. A., Tamura, R. E., Teixeira, E. C., Tezza, R. I. D., Trindade dos Santos, M., Truffi, D., Tsai, S. M., White, F. F., Setubal, J. C. and Kitajima, J. P. (2002) Comparison of the genomes of two Xanthomonas pathogens with differing host specificities. Nature 417, 459-463.

Duchaud, E., Rusniok, C., Frangeul, L., Buchrieser, C., Taourit, S., Bocs, S., Boursaux-Eude, C., Chandler, M., Dassa, E., Derose, R., Derzelle, S., Freyssinet, G., Gaudriault, S., Givaudan, A., Glaser, P., Medigue, C., Lanois, A., Powell, K., Siguier, P., Wingate, V., Zouine, M., Boemare, N., Danchin, A. and Kunst, F. (2003) The genome sequence of the entomopathogenic bacterium Photorhabdus luminescens. Nat. Biotechnol. 21, 1307-1313.

Enomoto, M., Oosawa, K. and Momota, H. (1983) Mapping of the pin locus coding for a site-specific recombinase that causes flagellar-phase variation in Escherichia coli K-12. J. Bacteriol. 156, 663-668.

Enomoto, M., Sakai, A. and Tominaga, A. (1985) Expression of an Escherichia coli flagellin gene, hag48, in the presence of a Salmonella H1-repressor. Mol. Gen. Genet. 201, 133135.

Guo, M., Manulis, S., Mor, H. and Barash, I. (2002) The presence of diverse IS elements and an avrPphD homologue that acts as a virulence factor on the pathogenicity plasmid of Erwinia herbicola pv. gypsophilae. Mol. Plant Microbe. Interact. 15, 709-716.

Hanafusa, T., Saito, K., Tominaga, A. and Enomoto, M. (1993) Nucleotide sequence and regulated expression of the Salmonella fljA gene encoding a repressor of the phase 1 flagellin gene. Mol. Gen. Genet. 236, 260-266.

Hanafusa, T., Sakai, A., Tominaga, A. and Enomoto, M. (1989) Isolation and characterization of Escherichia coli hag operator mutants whose hag48 expression has become repressible by a Salmonella $H 1$ repressor. Mol. Gen. Genet. 216,
$44-50$.

Ide, N., Ikebe, T. and Kutsukake, K. (1999) Reevaluation of the promoter structure of the class 3 flagellar operons of Escherichia coli and Salmonella. Genes Genet. Syst. 74, 113-116.

Inoue, Y. H., Kutsukake, K., Iino, T. and Yamaguchi, S. (1989) Sequence analysis of operator mutants of the phase-1 flagellin-encoding gene, fliC, in Salmonella typhimurium. Gene 85, 221-226.

Johnson, R. C. (2002) Bacterial site-specific DNA inversion systems. In: Mobile DNA II (eds.: N. L. Craig, R. Craigie, M. Gellert and A. M. Lambowitz), pp. 230-271. American Society for Microbiology, Washington, D. C.

Kunst, F., Ogasawara, N., Moszer, I., Albertini, A. M., Alloni, G., Azevedo, V., Bertero, M. G., Bessieres, P., Bolotin, A., Borchert, S., Boriss, R., Boursier, L., Brans, A., Braun, M., Brignell, S. C., Bron, S., Brouillet, S., Bruschi, C. V., Caldwell, B., Capuano, V., Carter, N. M., Choi, S. K., Codani, J. J., Connerton, I. F., Cummings, N. J., Daniel, R. A., Denizot, F., Devine, K. M., Duesterhoeft, A., Ehrlich, S. D., Emmerson, P. T., Entian, K. D., Errington, J., Fabret, C., Ferrari, E., Foulger, D., Fritz, C., Fujita, M., Fujita, Y., Fuma, S., Galizzi, A., Galleron, N., Ghim, S. Y., Glaser, P., Goffeau, A., Golightly, E. J., Grandi, G., Guiseppi, G., Guy, B. J., Haga, K., Haiech, J., Harwood, C. R., Henaut, A., Hilbert, H., Holsappel, S., Hosono, S., Hullo, M. F., Itaya, M., Jones, L., Joris, B., Karamata, D., Kasahara, Y., Klaerr-Blanchard, M., Klein, C., Kobayashi, Y., Koetter, P., Koningstein, G., Krogh, S., Kumano, M., Kurita, K., Lapidus, A., Lardinois, S., Lauber, J., Lazarevic, V., Lee, S. M., Levine, A., Liu, H., Masuda, S., Maueel, C., Medigue, C., Medina, N., Mellado, R. P., Mizuno, M., Moestl, D., Nakai, S., Noback, M., Noone, D., O'Reilly, M., Ogawa, K., Ogiwara, A., Oudega, B., Park, S. H., Parro, V., Pohl, T. M., Portetelle, D., Porwolik, S., Prescott, A. M., Presecan, E., Pujic, P., Purnelle, B., Rapoport, G., Rey, M., Reynolds, S., Rieger, M., Rivolta, C., Rocha, E., Roche, B., Rose, M., Sadaie, Y., Sato, T., Scanlon, E., Schleich, S., Schroeter, R., Scoffone, F., Sekiguchi, J., Sekowska, A., Seror, S. J., Serror, P., Shin, B. S., Soldo, B., Sorokin, A., Tacconi, E., Takagi, T., Takahashi, H., Takemaru, K., Takeuchi, M., Tamakoshi, A., Tanaka, T., Terpstra, P., Tognoni, A., Tosato, V., Uchiyama, S., Vandenbol, M., Vannier, F., Vassarotti, A., Viari, A., Wambutt, R., Wedler, E., Wedler, H., Weitzenegger, T., Winters, P., Wipat, A., Yamamoto, H., Yamane, K., Yasumoto, K., Yata, K., Yoshida, K., Yoshikawa, H. F., Zumstein, E., Yoshikawa, H. and Danchin, A. (1997) The complete genome sequence of the gram-positive bacterium Bacillus subtilis. Nature 390, 249-256.

Kutsukake, K., Ohya, Y., Yamaguchi, S. and Iino, T. (1988) Operon structure of flagellar genes in Salmonella typhimurium. Mol. Gen. Genet. 214, 11-15.

Kuwajima, G. (1988) Construction of a minimum-size functional flagellin of Escherichia coli. J. Bacteriol. 170, 3305-3309.

Ochman, H. and Wilson, A. C. (1987) Evolutionary history of enteric bacteria. In: Escherichia coli and Salmonella typhimurium: cellular and molecular biology (eds.: F.C. Neidhardt, J. L. Ingraham, K. B. Low, B. Magasanik, N. Schaechter and H. E. Umbarger), pp. 1649-1654. American Society for Microbiology, Washington, D. C.

Ratiner, Y. A. (1982) Phase variation of the H antigen in Escherichia coli strain Bi7327-41, the standard strain for Escherichia coli flagellar antigen H3. FEMS Microbiol. Lett. 15, $33-36$.

Ratiner, Y. A. (1987) Different alleles of the flagellin gene $h a g B$ in Escherichia coli standard $\mathrm{H}$ test strains. FEMS Micro- 
biol. Lett. 48, 97-104.

Ratiner, Y. A. (1998) New flagellin-specifying genes in some Escherichia coli strains. J. Bacteriol. 180, 979-984.

Salanoubat, M., Genin, S., Artiguenave, F., Gouzy, J., Mangenot, S., Arlat, M., Billault, A., Brottier, P., Camus, J. C., Cattolico, L., Chandler, M., Choisne, N., Claudel-Renard, C., Cunnac, S., Demange, N., Gaspin, C., Lavie, M., Moisan, A., Robert, C., Saurin, W., Schiex, T., Siguier, P., Thebault, P., Whalen, M., Wincker, P., Levy, M., Weissenbach, J. and Boucher, C. A. (2002) Genome sequence of the plant pathogen Ralstonia solanacearum. Nature 415, 497-502.

Sambrook, J., Fritsch, E. F. and Maniatis, T. (1989) Molecular cloning: a laboratory manual. Second edition. Cold Spring Harbor Laboratory Press, New York

Silverman, M., Zieg, J. and Simon, M. (1979) Flagellar-phase variation: isolation of the $r h 1$ gene. J. Bacteriol. 137, 517523

Steibl, H. D. and Lewecke, F. M. (1995) IS1222: analysis and distribution of a new insertion sequence in Enterobacter agglomerans. 339. Gene 156, 37-42.

Tominaga, A., Ikemizu, S. and Enomoto, M. (1991) Site-specific recombinase genes in three Shigella subgroups and nucleotide sequences of a pinB gene and an invertible B segment from Shigella boydii. J. Bacteriol. 173, 4079-4087.

Tominaga, A., Mahmoud, M. A.-H., Mukaihara, T. and Enomoto, M. (1994) Molecular characterization of intact, but cryptic, flagellin genes in the genus Shigella. Mol. Microbiol. 12, 277-285.

Umeda,M. and Ohtsubo, E. (1991) Four types of IS1 with differences in nucleotide sequence reside in the Escherichia coli K-12 chromosome. Gene 98, 1-5.

Zieg, J., Silverman, M., Hilmen, M. and Simon, M. (1977) Recombination switch for gene expression. Science 196, 170-172.

Zieg, J. and Simon, M. (1980) Analysis of the nucleotide sequence of an invertible controlling element. Proc. Natl. Acad. Sci. USA 97, 10567-10572. 